M/200,000 adenosine triphosphate, one hesitates, in view of the well-known difficulty of eliminating co-enzyme completely from the enzyme system, to accept the evidence for esterification without coenzymic intervention which has so far been provided.

L. P. KENDAL.

L. H. Stickland.

Department of Experimental Pathology

and Cancer Research,

School of Medicine,

Leeds.

July 28.

${ }^{1}$ Kendal and Stickland, J. Soc. Chem. Ind., 55, 1030 (1936).

'Needham, Ann. Rev. Biochem., B, 401 (1937).

${ }^{2}$ Cori and Cori, Proc. Soc. Exp. Biol. and Med., 34, 702 (1936).

- Ostern, Guthke and Terszakowec, Z. physiol. Chem., 243, 9 (1936).

${ }^{5}$ Lehmann and Needham, Biochem. J., 31, 329 (1937).

\title{
Growth Factors for Phycomyces
}

DURING the last three years, Schopfer has published several papers ${ }^{1}$ showing that vitamin $B_{1}$ is a growth factor for Phycomyces. This mould can now be grown on a synthetic medium composed of glucose, asparagine, inorganic salts and the vitamin. During the last two years, he has described ${ }^{2}$ an alternative growth factor ('MP') which differs from the vitamin in being resistant to heat $\left(128^{\circ} \mathrm{C}\right.$. for 20 hours causes only 75 per cent loss of activity) and resistant to alkali ; it is oxidized by hydrogen peroxide.

Knight ${ }^{3,4}$ has shown that his growth factor for Staphylococcus consists of three parts, two being the pyrimidine (I) and thiazole (II) components of vitamin $\mathrm{B}_{1}$ (III), and the third being nicotinic acid or its amide. Very recently Schopfer and Jung ${ }^{5}$ have stated that vitamin $B_{1}$ can be replaced as a growth factor for Phycomyces by the pyrimidine and thiazole components.<smiles>Cc1ncc(N)c(N)n1</smiles>

I<smiles></smiles>

III<smiles></smiles>

IV<smiles>Cc1ncsc1CCO</smiles>

II
Through the kindness of Dr. Todd, I had also been able to test four synthetic compounds ( $\mathrm{r}$, II, IV and v) as growth factors for Phycomyces. On a medium composed of glucose, asparagine and inorganic salts, no growth is obtained when these four compounds are added singly. But $I$ and II together give a very large growth (cf. Schopfer and Jung), IV and II a fair growth, while $\mathrm{v}$ and II give no growth. Further, a neutral solution of vitamin $B_{1}$, autoclaved for two hours at $125^{\circ} \mathrm{C}$., still acts as growth factor for Phycomyces, although the compound is destroyed. The activity of compounds I and IV is not destroyed by this treatment, even in presence of $N / 10 \mathrm{NaOH}$; hydrogen peroxide, however, destroys the activity. This supports Schopfer's suggestion that his factor ' $M P^{\prime}$ ' consists of degradation products of vitamin $B_{1}$. There is no doubt that vitamin $B_{1}$ itself, as well as its constituents, is a growth factor, since a solution sterilized by filtration through glass instead of by autoclaving remains active. Vitamin $B_{1}$ diphosphate ("co-carboxylase" of Lohmann), which was kindly supplied by Prof. Lohmann, is about as active as the vitamin itself.

\section{H. M. Sinclatr.}

Department of Biochemistry, Oxford.

June 29 .

${ }^{1}$ Schopfer, C.R. Acad. Sci., 200, 1965 (1935).

'Schopfer, Z. Vitaminforsch., 4, 187 (1937).

${ }^{3}$ Knight, Nature, 139, 628 (1937).

"Knight, Chem. and Ind., 56, 445 (1937).

${ }^{\circ}$ Schopfer and Jung, C.R. Acad. Sci., 204, 1500 (1937).

\section{Constituents of Vitamin E Concentrates from Rice- and Wheat-Germ Oils}

THE pioneer work of Evans and his collaborators on the anti-sterility factor (vitamin $\mathrm{E}$ ) has culminated in the isolation from the unsaponifiable fraction of wheat-germ ${ }^{1}$ and cotton-seed ${ }^{2}$ oils of three apparently isomeric oily alcohols $\alpha-\beta$ - and $\gamma$-tocopherol of approximate formula $\mathrm{C}_{28} \mathrm{H}_{50} \mathrm{O}_{2}$, all of which show high vitamin $\mathrm{E}$ activity. The use of the unsaponifiable fraction of rice-germ oil as a source of vitamin $\mathrm{E}$ was advocated by $\mathrm{Kimm}^{3}$, who later ${ }^{4}$ prepared from a purified concentrate a $\beta$-naphthoate, m.p. $156^{\circ}$, which yielded on hydrolysis a product alleged to have very high vitamin $\mathrm{E}$ activity.

By acylation of purified concentrates from the unsaponifiable portion of rice-germ oil with $p$-nitro. benzoyl chloride or $\beta$-naphthoyl chloride we obtained a complex mixture of oily and crystalline esters. The crystalline esters on separation and hydrolysis yielded three apparently homogeneous crystalline isomeric alcohols of formula $\mathrm{C}_{30} \mathrm{H}_{50} \mathrm{O},(a)$ m.p. $121^{\circ}-122^{\circ},(b)$ m.p. $113^{\circ}-114^{\circ}$ and $(c)$ m.p. $119^{\circ}-120^{\circ}$. The alcohol $(c)$ yields a $\beta$-naphthoate corresponding in its properties to that of Kimm's active material ; but like $(a)$ and $(b)$ it is devoid of vitamin $\mathrm{E}$ activity. Of these alcohols, $(a)$ may be polyterpenoid in nature but $(b)$ and $(c)$ are certainly akin to the sterols, being similar in their properties to the tritisterols obtained by Karrer and Salomon ${ }^{5}$ from wheat-germ oil concentrates. In a parallel investigation of wheat-germ oil we isolated in similar fashion $\beta$-amyrin and two isomeric alcohols $\mathrm{C}_{30} \mathrm{H}_{50} \mathrm{O}$ of the tritisterol type, $(d)$ m.p. $113^{\circ}-114^{\circ}$ and $(e)$ m.p. $175^{\circ}$; of these $(d)$ was also obtained by Karrer and Salomon. Neither $(d)$ nor (e) possessed vitamin $\mathbf{E}$ activity.

The purified oils remaining after removal of these crystalline alcohols from both rice and wheat concentrates had a high biological activity, and gave, on thermal decomposition, considerable quantities of durohydroquinone $\mathrm{C}_{10} \mathrm{H}_{14} \mathrm{O}_{2}$, which Fernholz ${ }^{8}$ obtained by similar treatment of pure $\alpha$-tocopherol. On treating the oil from the wheat concentrate with cyanic acid in benzene, a mixture of allophanates 